\title{
МЕТАФОРИЗАЦІЯ ОБРАЗУ "Я" У ТВОРЧОСТІ БОРИСА ОЛІЙНИКА
}

\author{
ОЛЬГА ДІБРОВА \\ Кременчуцький педагогічний коледж імені А. С. Макаренка, Кременчук - Україна \\ dibrova-olga-vit@ukr.net; ORCID: 0000-0002-7749-3582
}

\section{METAFORYZACJA OBRAZU “JA”W TWÓRCZOŚCI BORYSA OLIJNYKA}

\author{
OLGA DIBROWA \\ Krzemieńczuckie Kolegium Pedagogiczne imienia Antona Makarenki, \\ Krzemieńczuk - Ukraina
}

STRESZCZENIE. Artykuł poświęcony jest analizie metaforyzacji obrazu "Ja" w twórczości Borysa Olijnyka - przedstawiciela ukraińskiej literatury pięknej. Autorka bada metafory w tekście artystycznym, odnajdując nie tylko szczegóły kształtowania obrazów poetyckich, ale również właściwości kognitywnego stylu pisarza.

Słowa kluczowe: konceptualizacja, metafora, językowy obraz świata, przestrzeń artystyczna.

\section{METAPHORIZATION OF “I” IMAGE IN BORYS OLIYNYK’S POETRY}

\section{OLHA DIBROVA}

A. S. Makarenko Kremenchuk Pedagogical College, Kremenchuk - Ukraine

ABSTRACT. The article deals with the metaphorization of "I" image in the works of a Ukrainian poet Borys Oliynyk, the prominent representative of Ukrainian literature. The metaphors in the artistic text have been analyzed, which reveal not only the specificity of the formation of the verbal poetic images, but ultimately — the peculiarities of the cognitive style of the writer.

Key words: conceptualization, metaphor, linguistic picture of the world, artistic space.

$\mathrm{K}$

онцепт “людина" в художньо-семантичній площині Б. Олійника репрезентований багатогранно та пов' язаний із концептом “народ”. Однак люВона загадкова та незбагненна, тому мовно-поетична реалізація цього концепту неможлива без форми Я як репрезентації авторського світобачення. О. Маленко зазначає, що „поетичне мовомислення др. пол. ХХ ст. еволюційно наблизилося до теоретичних засад екзистенціоналізму й висвітлилося в розумінні людини як об’єкта, що не є закритою, статичною, окресленою структурою, а такою, що завжди «будує» себе, знаходиться в постійному пошукові й віднайдені свого, щоразу іншого, Я"1. Наголосимо, що сучасні лінгвістичні дослідження, що мають антропоцентричну орієнтацію, присвячені передусім вивченню мовного образу людини в художніх творах (К. Голобородько, І. Голубовська, С. Срмоленко, В. Калашник, Т. Космеда, Л. Лисиченко, Д. Лісничий, О. Маленко, А. Мойсієнко, М. Степаненко, О. Стишов, Г. Сюта та ін.).

${ }^{1}$ О. О. Маленко, Лінгво-естетична інтерпретація буття в украӥнській поетичній мовотворчості (від фольклору до постмодерну), Харків 2010, с. 363. 
Актуальність цієї розвідки зумовлена тим, що лексика семантичної категорії “людина" привертає постійну увагу дослідників, які вивчають людину у філософському, антропологічному, психологічному, соціологічному, історичному вимірах, тобто іiі природу, внутрішні та зовнішні характеристики, менталітет, вплив клімату й місця проживання на формування людини та ін. Учені різних галузей науки сходяться на тому, що витоки й наслідки уявлення людини про себе, або Я, заслуговують на серйозну увагу. Категорія Я є об'єктом дослідження у філософії, психології, культурології, соціології, літературознавстві та лінгвопоетиці. Філософія висуває таку дефініцію: „Я - це фундаментальна категорія філософських концепцій особистості, що виражає рефлексивно усвідомлену самототожність індивіда"2. Лінгвістичне тлумачення слова я полягає в такому: „1. Уживається мовцем для називання самого себе. 2. Уживається для позначення усвідомлюваної людиною власної сутності, себе в навколишньому світі"3. Концепт "я" - органічний складник антропоцентричності художньої творчості, він пов’язаний з вербалізацією уявлення про систему Я людини. Зокрема, у поетичних площинах творів Б. Олійника цей концепт відбиває сам образ автора та його життєвий шлях — неповторний і оригінальний. Сприйняття концепту мотивоване системою вербальних я-образів, що в текстово-інтерпретаційному аналізі поезій автора репрезентована відповідними мовними засобами.

Авторський мовосвіт Б. Олійника репрезентовано художньо-семантичними сферами $Я$ - природа, $Я$ - предмет, явище, $Я$ - сочіум. Як показує фактичний матеріал, найбільш активно поет використовує ті автометафори, де донорськими для побудови метафоричних конструкцій є сфери тварини й рослини. Л. Кравець і А. Вертепна зазначають: „Аналогізація ліричного героя, вираженого в тексті займенником $я$, , з іншим об'єктом $є$ автометафорою, своєрідною самоідентифікацією поета, спорідненою з міфологічним мисленням. Автометафора міститься на «перехресті» метафори й метаморфози"4. Такі метафори народжені з безпосереднього відчуття, коли автор „виділяє ту головну властивість або стан, що відповідає його природі'"5.

Я - природа. Найбільш продуктивний елемент метафоризації в цій сфері становлять зооморфні одиниці, що реалізуються через використання численних образів птахів, свійських і диких тварин, комах і плазунів, а також їхніх атрибутивних елементів. Напр., у мікротексті Став я ніжним, / став я птахом $i$ крилом 6 елементами донорської сфери метафори $є$ й узагальнювальна лексема nmax, і атрибутивна одиниця крило; в уривку Це так судилось: мені летіти, не долетіти / I зупинитися жайворово над твоїм серцем... (т. 1, с. 53) такими одиницями є дієслово летіти, що утворює ампліфікаційне повторення, і прислівник жайворово, що виконує синтаксичну функцію обставини способу дії, створюючи різку авторську метафору. Саме орнітологічні елементи цієї субсфери є улюбленими в Б. Олійника, вони творять порівняльні звороти: Б'юсь у скелі обелісків, / мов у кліті пташка... (т. 6, с. 8), де навіть дієслово б'юсь набуває орнітоморфної ознаки. Таку ж конотацію отримує дієслово бринить у поетичному рядку Крило моє бринить (т. 1, с. 81), оскільки воно спроектоване на орнітоморфний іменник крило. Лексема крило полісемантична й символічна.

\footnotetext{
${ }^{2}$ Всемирная эничклопедия: Философия, ред. А.А.Грицанов, Минск 2001, с. 285.

${ }^{3}$ Словник украӥнської мови, в 11 томах, ред. І.К.Біл оді д, Київ 1980, т. 11, с. 618.

${ }^{4}$ Л. Крав ець, Народнопоетична метафора в мовотворчості А. Малишка, Київ 2013, с. 14.

${ }^{5}$ Н. Д. Арутюнов а, Метафора и дискурс, Москва 1990, с. 30.

6 Б. І. О лі ій и к, Вибрані твори, у 6 томах, Київ 2007, т. 1, с. 56 - далі подаємо поклики на це видання в круглих дужках, зазначаючи конкретний том і сторінку.
} 
Порівняно з наведеними прикладами ця одиниця може виконувати й суто допоміжну функцію обставини способу дії, порівн.: ...я ж крилом до иъього берега npupic (т. 1, с. 70). Поетичне мовомислення Б. Олійника реалізується через лексику, що передає позитивні риси птахів. Позначений орнітонімом лебідь птах наділений силою, ніжністю, вірністю та жертовністю заради коханої. Ці риси й використовує поет у створенні метафоричних конструкцій. Напр.: Тоді прилинув лебедем і скрикнув на стерні (т. 1, с. 80) (семантичний показник ніжності дієслово прилинув, показник жертовності - скрикнув). Із часом (з віком) ознаки лебедя замінюються журавлиними: Я з останнього морозу від крила твого воскресну / як не лебедем, хоч сивим журавлем (т. 1, с. 70) (показник асоціативності журавля з похилим віком - прикметник-означення сивий; також тут наявна й паралель до авторської площина з орнітологічним метафоричним наповненням - твоє крило). Зрештою, лебідь і журавель - репрезентанти часових періодів життя ліричного героя. Також журавель у поета - символ журби за коханою, причому метафоричне перенесення цієї ознаки відбувається через звуконаслідувальну семантику закурличу: Заболю, затужу, / заридаю.. в собі, закурличу (т. 1, с. 54). Актуалізоване дієслово міститься в одному ряду однотипних за часом, видом і семантикою. Голуб-турман відрізняється унікальною манерою польоту: Летів до тебе турманом через моря $і$ дні...; Злечу у небо турманом востанне на біду (т. 1, с. 80). Це й відображено поетом через синтаксичну функцію обставини способу дії (летів турманом, злечу турманом). В обох цих рядках тісно пов'язані категорії простору й часу в єдиний хронотоп із загальним значенням летів - шукав багато років. Орнітоніми можуть передбачати й негативну семантику, напр., крук - смертельно небезпечний птах із славою лиховісника. Поет бачить у ньому ознаки внутрішніх відчуттів: Стою серед побоїща, мов крук (т. 6, с.19). У художньо-семантичній сфері природа Б. Олійник також використовує одиниці донорської сфери рослини, що об'єднує й самі фітоніми, і фітоморфні елементи. Напр., ознака цвітіння належить до часової метафоричної площини поезій, виражаючи ставлення поета до свого віку та стану: Я для інших одивів, / я під серием сховав свої квіти (т. 1, с. 54) (показники цієї ознаки - дієслово одивів та іменник квіти, показник часового виміру 一 дієслівна форма минулого часу доконаного виду). До фітоморфних елементів донорської субсфери рослини належить й одиниця гілки (у поета - віти): Але якось вночі / підійди і торкни мої віти / я тобі засвічусь, / як нікому іще не світивсь! (т. 1, с. 55). У цьому прикладі гілки аналогізуються із ширшою чуттєвою зоною. Як видається, це означає зацікавленість ліричним героєм, на яку той зреагує відповідною увагою. Традиційною одиницею цієї сфери є й листя, що може означати як крону дерева чи покривало, так і часовий вимір: Ми станем прахом, як осінне листя (т. 6, с. 25) (показник часу - прикметник-означення осіннє). Серед фітонімів, які Б. Олійник використовує в автометафорах, часто згадується клен: Нам легко, бо ми уже пам'яттю стали, мов клени (т. 2, с. 82) (порівняльний зворот указує на ототожнення кленів з людською пам'яттю). Це також може бути верба: А я лишуся на землі вербою, / з якої перше колесо пішло (т. 3, с. 34) (іменне словосполучення перше колесо вказує на древність верби та ії значення в культурі). Як людина українських степів, митець виявляє свою спорідненість з ознаками, що властиві місцевим травам - ковилю (Через всі тисячоліття / на дорозі перехресній / припаду до твого сліду ковилем (т. 1, с. 71)) та кураю (Куди вже пхатись, коли нас і досі / зі Сходу в Захід, мов курай, односить... (т. 3, с.119) (ботанічні ознаки тут корелюють 3 лексичними 
показниками: ковиль стелиться під ногами - припаду ковилем, а курай переноситься вітром - зі Сходу в Захід односить)). У другому прикладі наявні й одиниці часової та просторової парадигм - прислівник досі та сурядне словосполучення зі Сходу в Захід. Зрештою, автор нерозривно поєднує себе з природою, називаючи іiі “вічним древом планети”, тобто флороморфну одиницю дерево він ставить над усім, оскільки вона в цій сполуці є смисловим центром: $\mathrm{Ha}$ Дніпровій горі гей одкрився ж мені неокрай; / я відчув себе жолудем вічного древа планети (т. 5, с.108). Це дерево опосередковано асоціюється з дубом, оскільки поет себе бачить його жолудем (як відомо, „жолудь - плід дуба"7), тобто, 3 одного боку - мікроскопічною часткою (кількісний показник), а з другого - нерозривною його частиною (якісний показник). Знову очевидною є творча трансформація Б. Олійником архетипних метафор. Поет створює автометафору, у якій вербалізує архетипні метафоричні уявлення про природні стихії, що є частинами донорської макросфери природа, одиниці яких асоціюються з відчуттями автора. Визначаємо такі корелятивні зіставлювані пари: людина - вода, людина - вогонь, людина - вітер, людина - земля, людина - зірка. „Переоріснтація семантичних кодів (ентропія значень) відбувається при творенні багатьох словесних образів, особливо таких, що грунтуються на традиційних...". Отже, у метафоричному зіставленні “я - природа" для змалювання свого світобачення та внутрішніх почуттів Б. Олійник переважно вибирає автометафори з донорської сфери "птахи", напр., лебідь, журавель - показники відповідних часових (вікових) площин; “космонім” зірка - показник належності до світу природи та ін.

Я - предмет, явище. Ця художньо-семантична сфера передбачає корелятивні зв'язки, у яких беруть участь одиниці донорських макросфер предмети та явища. Напр., порівняння з карнизом позначає тверду основу, що підтримує нащадка героя, служить йому життєвим трампліном: I по мені колись, мов по карнизу, / нащадок ступить ближче до зорі (т. 6, с. 6) (формальний показник такого значення - дієслівне словосполучення ступить до зорi); порівняння зі склом позначає сприйнятливість героя до нового знання, самопізнання: I я відчув, як око те огненне / пройшло крізь мене, ніби через скло, / прозрівши все: $i$ до, i після мене (т. 6, с. 22) (семантичні показники - дієслівні сполуки пройшло крізь мене та прозрівши все; часовий показник - сполука $i$ до, $i$ після мене). Окрім власне порівняльної функції, автор зіставляє свої почуття з предметами: Одного я боюсь: цигаркою / продиміть на чужій губі (т. 3, с. 27) (іменник цицарка тут виконує функцію способу дії до складеного дієслівного присудка боюсь продиміть, що семантично означає 'провести життя даремно, ще й на чужу користь'); - Я - прах. Я - відлуння залізної роти заслону... (т. 6, с. 28) (анафоричне повторення особового займенника акцентує увагу на самохарактеристиці автора, в автометафорі він зіставляє себе з прахом і відлуннямпам'яттю; цю ж акцентацію підкріплює й синтаксична форма складеного іменного присудка, коли постпозитивна іменна частина постає у смисловому епіцентрі фрази) і явищами: Перша куля - у пам'ять. Я ж-nам'ять землі (т. 3, с. 67) (автор аналогізує себе з пам'яттю, що також акцентована через таку ж синтаксичну модель складеного іменного присудка).

Я - couуіум. У цій корелятивній сфері автор відображає почуттєві зв'язки 3 довколишніми об'єктами: 1) рідною матір'ю: Тож не бійся, не печалься, моя нене: / нас не втримає асфальт на якорях (т. 4, с. 53) (мати суб’єктивується

\footnotetext{
${ }^{7}$ Словник украӥнської мови..., т. 2, с. 543.

8 О. О. Маленко, Лінгво-естетична інтерпретачія буття..., с. 365.
} 
іменником неня в кличному відмінку, герой - особовим займенником ми в родовому відмінку); 2) рідною землею: Що я без тебе? Так собі - сірий суб 'єкт (т. 4, с. 9) (суб'єктивізація відбувається за допомогою особових займенників у складі питання щзо я без тебе?); 3) коханою жінкою: Бо ти мене любиш уже як відлітану пам'ять, / а я ж тебе так, як у двадиять, живою люблю! (т. 6, c. 49) (автор і об'єкт його любові ідентифікуються через традиційні сполуки „ти мене любиш” - „я тебе люблю”); 4) старими друзями: $B$ друзях я, немов у люстрі, пізнаю себе і рух (т. 5, с. 108) (значення друзів розкривається через їхне порівняння з люстрою-призмою, що допомагає авторові пізнати себе й усвідомити свої дії); 5) рідним сином: I ми стоїмо при началі орбіти, / $i$ я відчуваю, як досвід приходить до сина (т. 2, с. 83) (часовий вимір, що позначає життєву зрілість сина, визначається через дієслівне складне словосполучення-метафору стоїмо при началі орбіти, а відчуття цього автором - через таку ж мовопоетичну одиницю досвід приходить до сина). Однією з провідних тем поезії Б. Олійника $є$ його спогади та характеристика власного життя, що відбувається в часово-просторових парадигмах і має концептуальне підгрунтя. Розпочинається цей опис з етнічної ідентифікації: Я тим уже боржник, що украӥнець зроду (т. 1, с. 18). Далі поет звертається до образу долі, що “заверстала” його життєвий шлях: Мені доля вручила перстень / $і$ сказала, що вже до смерті / я розмічений $і$ заверстаний / в наростаючу круговерть (т. 3, с. 27). За тлумачим словником верстати в першому значенні - 'пересуватися в певному напрямку' (порівн.: верста як просторовий вимір), тобто це значення безпосередньо вказує на життєвий шлях. Однак друге значення - типографське - 'розташовувати набір тексту на сторінках" має глибшу семантику: означає 'планування, визначення життя наперед’. Саме це значення покладено в основу авторської різкої метафори доля вручила перстень. I тому Усе, що мав, $i$ все, що на віку / дісталося мені від долі-посіванки (т. 1, с. 20). У цьому прикладі образ долі отримує ще й додатковий смисл, виражений через прикладку посіванка (на життєвій ниві посіяно всі життєві пригоди - у часовому вимірі „усе, що мав, і все, що на віку" - відповідно в минулому та майбутньому). У часовому проміжку життя поета простежуються такі етапи: дитинство, шкільні роки, роки утвердження творчої особистості, роки публічної слави, роки перемог на поетичному Олімni, роки усвідомлення батьківської науки, що згодом передається синові, сьогодення, коли поет оиінює пройдене життя, визначаючи як негативні моменти власного поводження, так і позитивні, моменти духовних підсумків. Не так часто, але тема кохання проходить через метафоричний життєпис Б. Олійника (I хлюпне мені тремкою прохолодою / твоїх пальиів лебедино-біла музика (т. 1, с. 52)), виявляючи ніжне ставлення до об'єкта кохання (показники - порівняння пальијв з музикою, а також авторський епітет лебедино-біла); Я тебе любив, я так любив, / горе моє, зоре, ладо-знадо, / що слова од щастя розгубив (т. 1, с. 76) (уплітається рефреновий мотив ладо-знадо з модальним зворотом горе моє). Однак більшою мірою тема кохання в поета поєднана семантично $з$ гіркою іронією (А любов моя з синім бантом / до практичнішого пішла (т. 3, с. 28) та печаллю: Це тому, що мені в сериі / поселилась тиха мука... і далі: Це тому, що... ие тому, що... ие тому, / що на обрії моєму засвітилася розлука (т. 1, c. 65), де показником печалі $є$ іменники мука та розлука, а показником почуття кохання - повтори та недоговореності - своєрідна ампліфікація в межах одного рядка. Семантика печалі в різних іiї проявах - одна з провідних у поезії

\footnotetext{
${ }^{9}$ Словник украйнської мови..., т. 1, с. 331.
} 
Б. Олійника. Вона зумовлена такими чинниками, як відчуття одинокості, утрати об'єкта ліричного захоплення, відчуття неможливості щастя, страху, невблаганності долі, спонтанність, незрозумілість причини такого відчуття, відчуття невблаганності часу. Провідна тема сьогоденного періоду творчості Б. Олійника - боротьба за мир, любов до Землі, України, хоча поет часто сумно іронізує щодо свого місця в сучасному світі. Напр.: Чом у власній хаті / я тулюсь, як бідний гість, / за порогом, брате? (т. 6, с. 159) (показник - антитезні протиставлення у власній хаті - тулюсь, як бідний гість). Раніше ж у поезії з промовистою назвою Вибір автор з гордістю оголошував про свої амбіційні наміри допомогти світові: Я б вибрав найвищу почесть: / у чистім і чеснім бою / на чорному мармурі ночі / зорю записати свою! (т. 3, с. 16) (протиставлення темряви - чорного мармуру - та світла - зорі, яку саме він мусить засвітити-записати); прославити на весь світ Україну: Я з поезій зведу вам до Києва міст, / котрий витрима наступ століть (т. 3, с. 67) (свої поезії він порівнює з мостом, що поєднує світ і Київ-Україну). Поет відчував свою місію творчої особистості, яка мусить бачити все, що відбувається у світі: У вікно моє, завще розилющене, / пильно дивляться тисячі вікон (т. 5, с. 61) (через дієприкметник-означення розплющене вікно аналогізується з очима, що пов'язані зі світом - тисячами таких самих очей). Подібна амбіційність і в поезії Дума про місто: на цій Горі, в зеніті безгоміння / стою один під хорами небес / $і$ чую, як з верха і до коріння / Гора - в мені, $і$ я -у ній увесь (т. 6, с. 6). Кожен рядок цієї строфи - указівка на вищезазначену місію: стою - на Горі, в зеніті, під хорами небес, з верха $i$ до коріння Гора в мені. Цими сполуками поет визначає свою роль у світі, беручи на себе місію його рятівника. Власні поезії, що покликані захистити Землю, автор метафорично називає цілющими: Земле!.. $<\ldots>$ / Я окроплю твою рану иілюшим зерном (т. 3, с. 10). Він визначає напрямок і рівень небезпеки для світу: На захід я глянув - i зблід: / бо там, на обвугленім тлі, / громадились хмари подерті, / погрожсючи Землі / холодною кригою смерті (т. 5, с. 53) (формальні показники негативної семантики - дієслівні форми зблід, громадились, погрожуючи, прикметники подерті, холодна, іменні словосполучення обвуглене тло, крига смерті). Поет гіперболізує прикмету “холодна", додаючи означення до такого ж за семантикою іменника крига. В актуальній площині часу поезії Б. Олійника більше отримують філософського наповнення, а він сам зводить себе до частинки Всесвіту, розуміючи людську запрограмованість і невмолимість часу: Віки лежать спресовані, як сходи, / а я живий, покіль іще стою / до того дня, коли рука природи / вкладе у пласт минущу плоть мою (т. 6, с. 6) (показник вищості природи - сполука вкладе у пласт минущу плоть мою, де прикметник минуща означає прив'язаність автора саме до проминального). Амбіційність поета як рятівника світу змінилася на споглядання та розуміння себе як частки природи: I я відчуваю, як сонщем напоєний вітер / у грудях потужно живлющим струмком виграє (т. 6, с. 48). Це відчуття-сприйняття (показники іменна та дієслівна сполуки сонщем напоєний вітер і живлющим струмком виграє) доповнюється любов’ю до України та Шевченка як українського месії: $T u$ в моєму сериі, Україно, / думою Шевченка гомонии (т. 4, с. 15).

Отже, концепт "я" - органічний складник творчості Б. Олійника. Він пов'язаний з вербалізацією уявлення про відповідну систему авторського “я”, що виражена низкою автометафор. Мовосвіт поета репрезентований художньосемантичними сферами $Я$ - природа, $Я$ - предмет, $Я$ - соиіум, де образ автора метафоризується за допомогою одиниць донорських сфер, серед яких біль- 
шою мірою виділяються явища та об'єкти природи, птахи, рослини, Земля, cвim, pодина. А часова парадигма відтворює етапи життя поета часто з використанням таких образів, як осінь, мороз, журавель як ознак похилого віку, якому митець присвячує свої поетичні тексти.

\section{Список використаної літератури}

Арутюнова Н. Д., Метафора и дискурс, Москва 1990.

Всемирная энщиклопедия: Философия, ред. А. А. Грицанов, Минск 2001.

Кравець Л., Народнопоетична метафора в мовотворчості А. Малишка, Київ 2013.

Маленко О. О., Лінгво-естетична інтерпретація буття в украйнській поетичній мовотворчості (від фольклору до постмодерну), Харків 2010.

Олійник Б. І., Вибрані твори, у 6 томах, Київ 2007.

Словник української мови, в 11 томах, ред. І. К. Білодід, Київ 1970-1980.

\section{Spysok vykorystanoi literatury \\ [References]}

Arutyunova N. D., Metafora i diskurs [Metaphor and Discourse], Moskva 1990.

Vsemirnaya e nciklopediya: Filosofiya [International Encyclopedia: Philosophy], red. A. A. Griczanov, Minsk 2001.

Kravets L., Narodnopoetychna metafora v movotvorchosti A. Malyshka [Folk Poetic Metaphor in Language Creative Work of A. Malyshko], Kyiv 2013.

Malenko O. O., Linhvo-estetychna interpretatsiia buttia v ukrainskii poetychnii movotvorchosti (vid folkloru do postmodernu) [Linguo-Esthetic Interpretation of Being in Ukrainian Poetic Language Creation (from Folklore to Modern)], Kharkiv 2010.

Oliinyk B. I., Vybrani tvory [Selected Works], u 6 tomakh, Kyiv 2007.

Slovnyk ukrainskoi movy [The Ukrainian Language Dictionary], v 11 tomakh, red. I. K. Bilodid, Kyiv 1970-1980. 